\title{
POJOKBELIA : THE STUDY OF SMART PHONE APPLICATION DEVELOPMENT AS COMMUNICATIVE, INFORMATIVE AND EDUCATIVE (KIE) MEDIA INNOVATION FOR ADOLESCENT REPRODUCTIVE HEALTH
}

\author{
Lita Heni Kusumawardani', Muhamad Jauhar', Rasdiyanah', \\ I Gusti Ayu Putu Desy Rohana ${ }^{1}$
}

1. Community Nursing Spesialist Program, Faculty of Nursing Science, University of Indonesia, Depok

2. Nursing Department, State Health Polytechnic of Semarang, Semarang

\begin{abstract}
Adolescent has curiosities, like challenges, and dare to take risks. The impact is unwanted pregnancy, sexual transmition diseases, and abortion. Therefore, there is a need of KIE media for adolescent reproductive health based on information technology: smart phone applications.

To identify about smart phone use as KIE media for adolescent reproductive health.

Literature study in 20 journals through Google Scholar, Proquest, and EBSCO in the last 5 years, keywords adolescent reproductive health, health education, smartphone application. Data were analyzed in tables contain title, author, year, methodology, result, and recommendation.

Smartphone application as KIE media for adolescent reproductive health effectively increased the connection of adolescents with parents and health workers, improved sexual transmition diseases screening, was more attractive and innovative, took into privacy, was accurate information, wider reach, easy access, affordable costs, interactive, practical, and appropriate to the needs of today's adolescent. Smartphone applications such as text message, social media, and website could help adolescent access to get fast and accurate health information. The media development needs to focus on the characteristics and needs of adolescent and can be integrated with adolescent health programs.
\end{abstract}

Keyword : adolescent, media, reproductive health, smart phone application

\section{ABSTRAK}

Remaja memiliki rasa ingin tahu, menyukai tantangan, dan berani menanggung risiko. Dampak dari remaja yang tidak mampu menghadapi tantangan adalah perilaku berisiko diantaranya kehamilan tidak diinginkan, penyakit menular seksual, dan aborsi. Berdasarkan hal tersebut, perlu adanya intervensi yang sesuai dengan karakteristik remaja saat ini yakni aplikasi telepon pintar.

Mengidentifikasi artikel-artikel penelitian tentang penggunaan telepon pintar sebagai media KIE kesehatan reproduksi remaja.

Mengidentifikasi artikel-artikel penelitian tentang penggunaan telepon pintar sebagai media KIE kesehatan reproduksi remaja.

Kajian literatur pada 20 jurnal melalui Google Scholar, Proquest, dan EBSCO dalam 5 tahun terakhir, kata kunci adolescent reproductive health, health education, smartphone application. Data dianalisis dalam tabel berisi judul, penulis, tahun, metodologi, hasil, dan rekomendasi.

Aplikasi telepon pintar sebagai media KIE kesehatan reproduksi remaja efektif meningkatkan ikatan remaja dengan orang tua dan tenaga kesehatan, meningkatkan skrining penyakit menular seksual, lebih menarik, inovatif, memperhatikan privasi, keakuratan informasi, jangkauan luas, akses mudah, biaya terjangkau, interaktif, praktis, dan sesuai dengan kebutuhan remaja saat ini.

Aplikasi telepon pintar seperti pesan teks, media sosial, website dapat membuka akses remaja untuk medapatkan informasi kesehatan yang cepat dan akurat. Pengembangan media ini perlu memperhatikan karakteristik dan kebutuhan remaja dan dapat diintegrasikan dengan program kesehatan remaja.

Keywords : remaja, media, kesehatan reproduksi, aplikasi telepon pintar 


\section{INTRODUCTION}

Adolescence is transitional period of physical, psychological and intellectual growth and development. Adolescents feel curious, like adventures and challenges and dare to take risk without careful consideration. Based on 2016 BKKBN report, the number of adolescents in Indonesia reach 66.3 million (25.6\%) (Kementerian Kesehatan RI, 2018). Adolescents have many challenges both from within and from the environment. Adolescents who are unable to deal with these challenges have impacts on complex health problems resulted from their risk behavior. So that, adolescents can be categorized as vulnerable or risk group (Kementerian Kesehatan RI, 2018).

The results of 2015 School-Based Health Survey in Indonesia explained that risk behavior in adolescents included smoking (45.8\%), drinking alcohol (20\%), drugs $(2.6 \%)$, premarital sexual behavior $(12.4 \%)$, and unwanted pregnancy (1.97\%) (Kementerian Kesehatan RI, 2018). Premarital sexual behavior was caused by several factors included curiosity (57.5\%), just happening (38\%), and being forced by partner (12.6\%). Premarital sexual behavior has the effect of transmitting sexual transmition diseases, adolescence marriages, unwanted pregnancies, and abortions. Based on the United Nations Development Economic and Social Affairs in 2010, Indonesia is one of the countries with the highest percentage of marriage at the age of 16 years. This is risky to the their lives due to insufficient readiness on health, emotional, socio-economic and reproductive aspects (Kementerian Kesehatan RI, 2018).

Adolescence pregnancy has risk for preterm birth, low birth weight, postpartum hemorrhage, and mother and baby mortality. Director General of P2PL report until 2017, that the incidences of HIV/AIDS increase in the age group of 2029 years (Kementerian Kesehatan RI, 2018). Based on the survey results, adolescents understanding in reproductive health is inadequate, it is proven that only $35.3 \%$ of adolescents know that women can get pregnant with one sexual relationship, 9.9\% know HIV / AIDS comprehensively, $15.3 \%$ know the symptoms of sexual transmition diseases, and $7.2 \%$ know adolescent reproductive health information and counseling service facilities (Sarweni \& Hargono, 2010).

Based on these phenomena, adolescents health problems require special management involving all parties. The adolescent health program is currently regulated by Permenkes No. 25 of 2014 through the School Health Efforts (UKS) and Youth Care Health Services (PKPR) which exist in 5,051 health centers, 514 districts / cities. Through this program, adolescents are expected to be able to live clean and healthy, have good health and social life skills. Provided Services are $\mathrm{KIE}$, counseling, coaching, peer counseling, clinical services, referral, and empowerment. But now, the interest and awareness of adolescents to use the program are still lack. adolescents seek more information about reproductive health from other sources (Kementerian Kesehatan R, 2018).

Many sources of information about adolescent reproductive health, they need to be controlled so they do not cause misperceptions. Adolescents often access reproductive health information that is incomplete, inaccurate, untrue, even misleading. These happen because of the rapid stream of information through various uncontrolled media (Sarweni \& Hargono, 2010). Based on this, it is necessary to have accurate, innovative KIE media based on the characteristics of adolescents and answer the needs of today adolescents by utilizing information technology and integrated with the available adolescent health services.

Information technology utilization is needed where today adolescents as millennial generation in the modernization era cannot be separated from the use of smartphones as social media, communication and information. The number of internet users in Indonesia until 2014 reached 88 million people. Patel, Masyukova, Sutton, \& Horvath, (2016) explained that $67.6 \%$ use smartphones to access the internet and social media, $87.3 \%$ access the internet and social 
media sites for 20-50 hours per week. This is an opportunity in the development of KIE media for adolescent reproductive health. Indonesia is the fourth country in the world with smartphone users. There are $80 \%$ of 82 million smartphone users in Indonesia, they are teenagers around 1519 years old (Kominfo RI, 2014). Based on the UNICEF report, it is found $98 \%$ of adolescents age 10-19 years know about internet (Panji, 2014).

The prevalence of diabetes mellitus (DM) has rapidly increased in the last 5 years. In Indonesia, the prevalence of DM is estimated to increase from 10.3 million in 2017 to 16.7 million in 2045 (International Diabetes Federation, 2017). Indonesian Basic Health Research (Riskesdas) showed that the prevalence rate of DM in Central Java, Maluku, South Sulawesi and East Nusa Tenggara reached the national average (2.1\%) (Badan Penelitian dan Pengembangan Kesehatan Departemen Kesehatan RI, 2013). According to medical records of General Hospital dr. R. Goeteng Taroenadibrata Purbalingga, Central Java, the number of patients with DM who visited outpatient clinic has increased from 3.047 in 2014 (2.017 women and 1.030 men) to 5.451 in 2016 (3.671 women and 1.780 men).

Health is defined as good physical, mental and social conditions and everyone is able to live productively (Kementerian Kesehatan RI, 2009). From the biological perspective, adolescent girls will normally experience first menstruation at age of 13-14 years. The age of menarche is a sign of puberty so they usually remember it (Must et al., 2002). In a pathological condition, earlier menarche (8-11 years old) increases the risk of polycystic ovary syndrome and type 2 DM (T2DM) (Mueller et al., 2014; Elks et al.,
2013). Women with polycystic ovary syndrome have 5-8 times higher risk of developing T2DM than women without polycystic ovary syndrome (Pan, Chen, Tsao, \& Chen, 2015). Another study has indicated that higher risk of T2DM in adolescences or young adults was found in women with gestational DM (Mueller et al., 2014).

\section{AIM}

To identify the use of smart phones in the promotion of adolescent reproductive health in several countries so that they can be used as references for the development of media to promote adolescent reproductive health in Indonesia.

\section{METHOD}

Journal searching was carried out comprehensively through the Google Scholar, Proquest and EBSCO research journal databases in the last 5 years. Keywords used in the search of research journal were adolescent reproductive health, health education, smartphone application. Journal searching used punctuation "AND" so that the writing "adolescent reproductive health and health education" and "health education and smartphone application". The obtained data were presented in table contained title, author, year, methodology, result, and recommendation and then analyzed by researchers. The inclusion criterias are articles published 2013-2018, all of articles type such as original research, literature or systematic review, adolescent reproductive health, health education, and smartphone application keywords. The exclusion criterias is articles not indexed in journals. The following is how to select articles: 


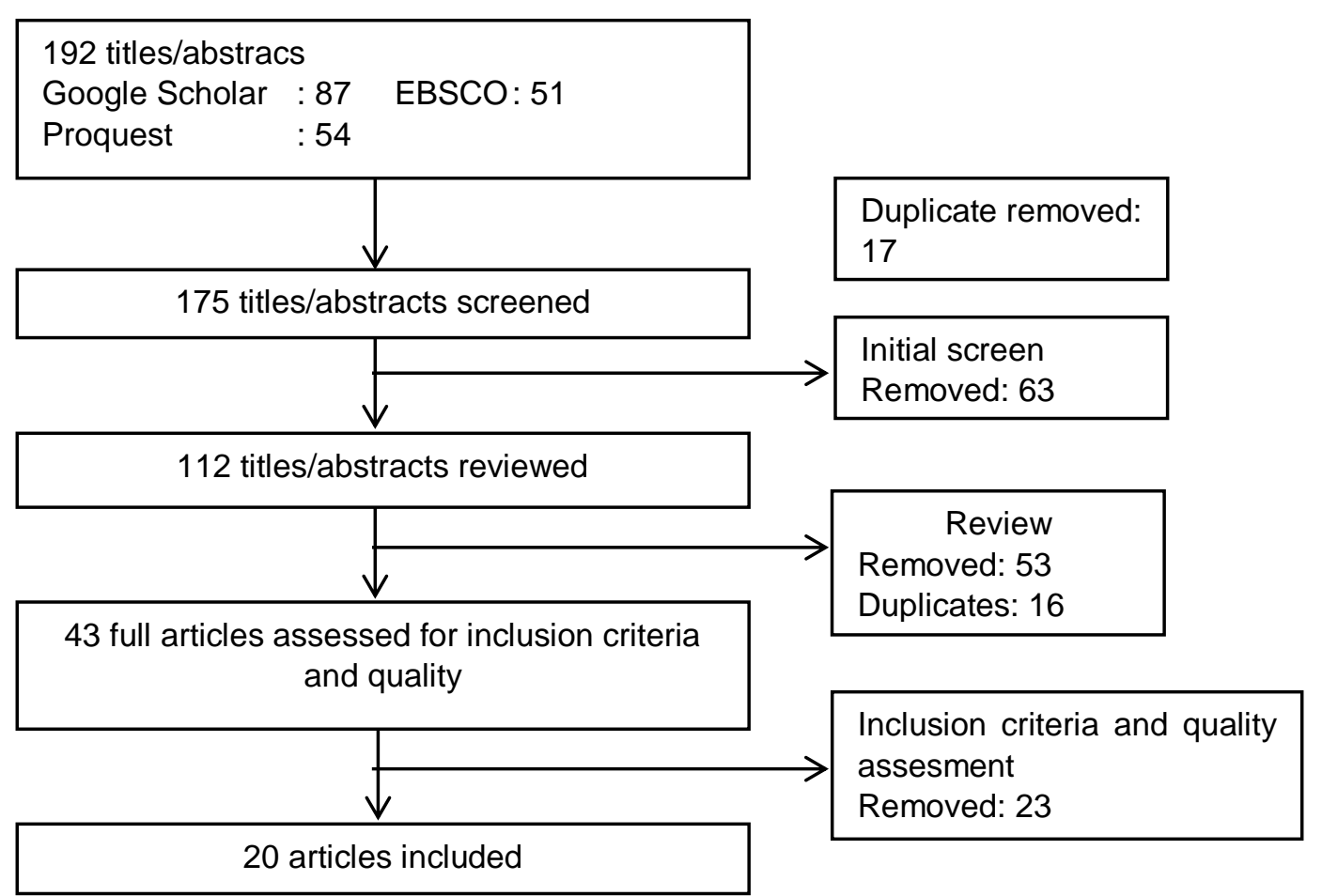

Figure 1: Article selection based on inclusion and exclusion criteria

\section{RESULT AND DISCUSSION}

Based on the articles that had been analyzed, the utilization of smartphone applications in various countries was able to overcome adolescent reproductive health problems such as early pregnancy, reproductive organ cancer, difficulty accessing contraception, unsafe abortion, increased cases of HIV / AIDS and high transmission of sexual transmition infections (IMS). In addition, the use of smart phone applications also increased the motivation of adolescents to access reproductive health information, connection among parents and health workers, the number of visits to health services, and the increase of sexual transmition diseases screening. The followings are summary of articles that had been analyzed : 


\section{Table 1. The summary of articles on the use of smart phone applications as KIE media for adolescent reproductive health in $2013-2018$ ( $\mathrm{n}=\mathbf{2 0}$ )}

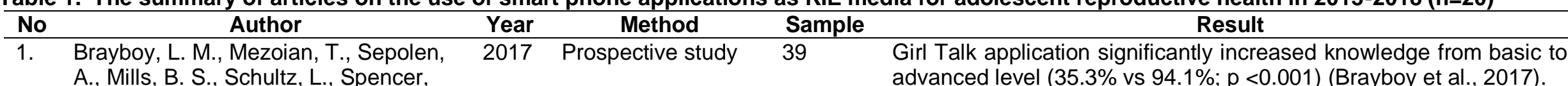

A., Mills, B. S., Schultz, L., Spencer, advanced level (35.3\% vs 94.1\%; $p<0.001)$ (Brayboy et al., 2017).

2. Sookyung Jeong, Chiyoung Cha and Jacob Lee

\section{Non-equivalent control-group time- \\ 88} series
The use of smartphone applications for 5 weeks was more effective than booklets in sexual transmition diseases health education programs. The average value of knowledge for the experimental group was 22.72 while for the control group was 16.83 , self-efficacy of the prevention of sexual transmition diseases in the experimental group was 12.40 while for the control group was 10.27 (Jeong, Cha \& Lee, 2017).

3. Slawa Rokicki, Jessica Cohen, Joshua

2017 Clusterrandomized controlled trial

4. Joyce Mazza Nunes Aragão, Fabiane do Amaral Gubert, Raimundo Augusto Martins Torres, Andréa Soares Rocha 2018 Qualitative descriptive study

$756 \quad$ Knowledge increased from $26 \%$ to $32 \%$ in the control group and $31 \%$ to $60 \%$ in the intervention group (Rokicki, Cohen, Salomon, \&

96 Fink, 2017). interactively, pleasantly, practically, privacy and brought adolescents closer to health care facilities so it had strengthen the connection between adolescents and health workers (Aragão, Gubert, Torres, Silva, \& Vieira, (2018).

Vieira

5. Judith B. Cornelius, Jacek Dmochowski, Cherrie Boyer, Janet St. Lawrence, Marguerita Lightfoot, Michael Moore

2013 Longitudinal one- 40 group comparison design

The number of adolescents who reported unprotected sexual intercourse from 31 times at the beginning to 19 times postintervention and then decreased to 9 times in 3 months after the use of BART text messages. Knowledge of HIV based on age increased significantly $(p=0.05)$, attitudes towards condoms increased significantly $(p=0.007)$ and HIV risk based on age increased significantly $(p=0.03)$ and time $(p=0.009)$ (Cornelius, Dmochowski, Boyer, Lawrence, Lightfoot, \& Moore, 2013).

6. Sheana S. Bull, Deborah K. Levine, Sandra R. Black, Sarah J. Schmiege, John Santelli

2013 Cluster randomized 1578 controlled trial

The time and effect of the intervention was observed for 2 months for condom use (intervention group 68\%, control group 56\%, p value $=0.04$ ) and proportion of sexual behavior using condoms (intervention group 63\%, control group 57\%, $p=0,03$ ). There were no visible effects at 6 months

(Bull, Levine, Black, Schmiege, \& Santelli, 2013).

7. Rebecca R. Ortiz, Autumn Shafer, 2018 Participatory action 108

Knowledge of adolescents in the intervention group increased 


\begin{tabular}{|c|c|c|c|c|c|}
\hline No & Author & Year & Method & Sample & Result \\
\hline & $\begin{array}{l}\text { Joan Cates, and Tamera Coyne- } \\
\text { Beasley }\end{array}$ & & research & & $\begin{array}{l}\text { compared to the control group. Knowledge score of the intervention } \\
\text { group was } 4.45(\mathrm{SD}=2.31) \text { to } 5.88(\mathrm{SD}=2.04) \text {. Knowledge scores } \\
\text { in the control group were } 3.31(\mathrm{SD}=2.25) \text { to } 3.68 \text { ( } \mathrm{SD}=2.5) \text {. } \\
\text { Teenagers conducted interpersonal discussions with others what } \\
\text { they had learned (Ortiz, Shafer, Cates, \& Coyne-Beasley, 2018). }\end{array}$ \\
\hline 8. & $\begin{array}{l}\text { Nadia Dowshen, Susan Lee, B. Matty } \\
\text { Lehman, Marné Castillo dan Cynthia } \\
\text { Mollen }\end{array}$ & 2015 & $\begin{array}{l}\text { Non-randomized } \\
\text { intervention }\end{array}$ & 1500 & $\begin{array}{l}\text { There were } 46 \% \text { of adolescents had never been examined, but } 70 \% \\
\text { planned to check in the next } 6 \text { months. The number of GC / CT tests } \\
\text { and positive results did not show significant difference before and } \\
\text { after social media campaigns, there was an increase in Syphilis } \\
\text { visits ( } 5.4 \text { vs } 18.8 \% ; p<0.01 \text { ) and HIV ( } 5.4 \text { vs } 19.0 \% \text {; } p<0.01) \text {. } \\
\text { Examinations were carried out after the launch of social media } \\
\text { campaign (Dowshen, Lee, Lehman, Castillo\& Mollen, } 2015) \text {. }\end{array}$ \\
\hline 9. & $\begin{array}{l}\text { Vincent Guilamo-Ramos \& Jane J. Lee } \\
\text { \& Leslie M. Kantor \& Deborah S. } \\
\text { Levine \& Sarah Baum \& Jennifer } \\
\text { Johnsen }\end{array}$ & 2014 & Qualitative & 168 & $\begin{array}{l}\text { The use of online and mobile technologies (OMT) could increase the } \\
\text { motivation of parents and adolescents to obtain reproductive health } \\
\text { information because of broad and accountable access (Guilamo- } \\
\text { Ramos et al., 2014). }\end{array}$ \\
\hline 10. & $\begin{array}{l}\text { Lianne Gonsalves, Michelle J. Hindin, } \\
\text { Angela Bayer, Cesar P. Carcamo, } \\
\text { Peter Gichangi, Ndema Habib, } \\
\text { Jefferson Mwaisaka dan Lale Say }\end{array}$ & 2018 & $\begin{array}{l}\text { Randomized } \\
\text { controlled trial }\end{array}$ & 705 & $\begin{array}{l}\text { Reproductive Mobile Access and Delivery Initiative for Love and Life } \\
\text { Outcomes (ARMADILLO) through telephone text messages } \\
\text { provided sexual reproductive health information to adolescents, easy } \\
\text { access for adolescents in certain groups (Gonsalves et al., 2018). }\end{array}$ \\
\hline 11. & $\begin{array}{l}\text { Kara Burns, Patrick Keating dan } \\
\text { Caroline Free }\end{array}$ & 2016 & Systematic review & 10 & $\begin{array}{l}\text { A total of } 10 \text { randomized control trials were identified ( } 9 \text { using the } \\
\text { control group). Targeted trials: sexual health service absorptive } \\
\text { promotion, 2) sexual risk behavior and } 3 \text { ) efforts to reduce bias data } \\
\text { in reporting sexual activity via SMS (Burns, Keating, \& Free, 2016). }\end{array}$ \\
\hline 12. & Nicole B. Ippoliti dan Kelly L’Engle & 2017 & Quasi experimental & 17 & $\begin{array}{l}\text { MHealth is used as a health promotion tool (82\%) could improve the } \\
\text { knowledge and behavior of adolescent reproductive health. MHealth } \\
\text { connected users with information on adolescent reproductive health, } \\
\text { counseling and family planning, abortion and post-abortion care } \\
\text { services, as well as HIV care and treatment (Ippoliti \& L'Engle, } \\
2017 \text { ). }\end{array}$ \\
\hline 13. & $\begin{array}{l}\text { Lianne Gonsalves, Kelly L. L'Engle, } \\
\text { Tigest Tamrat, Kate F. Plourde, Emily } \\
\text { R. Mangone, Smisha Agarwal, Lale } \\
\text { Say and Michelle J. Hindin }\end{array}$ & 2015 & $\begin{array}{l}\text { Quantitative- } \\
\text { experimental } \\
\text { studies }\end{array}$ & 160 & $\begin{array}{l}\text { ARMADILLO text message service was about family planning and } \\
\text { contraception information, it was innovative, personal, and easily } \\
\text { accessible provided. SMS ARMADILLO was designed for } \\
\text { communication media that were legal (Gonsalves et al., 2015). }\end{array}$ \\
\hline 14. & Carinne Brody, Sovannary Tuot, & 2018 & Quantitative- & 600 & Mobile health intervention improved reproductive health. There were \\
\hline
\end{tabular}




\begin{tabular}{|c|c|c|c|c|c|}
\hline No & Author & Year & Method & Sample & Result \\
\hline & $\begin{array}{l}\text { Pheak Chhoun, Dallas Swendenman, } \\
\text { Kathryn C. Kaplan dan Siyan Yi1 }\end{array}$ & & $\begin{array}{l}\text { randomized } \\
\text { controlled trial }\end{array}$ & & $\begin{array}{l}\text { increases in condom use, HIV and STI screening and treatment, } \\
\text { contraceptive use, decreased gender-based violence, behavior } \\
\text { changes in the use of reproductive health services (Brody et al., } \\
\text { 2018). }\end{array}$ \\
\hline 15. & $\begin{array}{l}\text { Nisa Novaeni, Dharminto, Farid } \\
\text { Agusyahbana, Atik Mawarni }\end{array}$ & 2018 & $\begin{array}{l}\text { Research and } \\
\text { development }\end{array}$ & 35 & $\begin{array}{l}\text { A total of } 35 \text { adolescents showed applicative assessment } \\
\text { percentage of } 85 \% \text { (very good). The application of Android-based } \\
\text { adolescent reproductive health could increase the understanding of } \\
\text { reproductive health, be more interesting, easily understood and } \\
\text { remembered about the materials, increased learning motivation, and } \\
\text { based on needs (Novaeni, Dharminto, Agusyahbana, dan Mawarni, } \\
2018 \text { ). }\end{array}$ \\
\hline 16. & Muflih Muflih, Deden Iwan Setiawan & 2017 & $\begin{array}{l}\text { Quasi-experiment } \\
\text { one group pre-post } \\
\text { test design }\end{array}$ & 450 & $\begin{array}{l}\text { There was an increase of } 6.96 \text { SD in adolescents self-efficacy after } \\
\text { getting information through media sms with a value of } p=0,000 \\
\text { (Muflih \& Setiawan, 2017) }\end{array}$ \\
\hline 17. & $\begin{array}{l}\text { Anindita Muslimah dan Denny Anggoro } \\
\text { Prakoso }\end{array}$ & 2014 & $\begin{array}{l}\text { Quasi-experiment } \\
\text { dengan control } \\
\text { group design pre- } \\
\text { test and post-test }\end{array}$ & 76 & $\begin{array}{l}\text { Health education through text message could significantly increase } \\
\text { knowledge with } p=0,000(p<0,05) \text { (Muslimah dan Prakoso, 2014). }\end{array}$ \\
\hline 18. & $\begin{array}{l}\text { Martha J. Decker, Nancy F. Berglas, } \\
\text { dan Claire D. Brindis }\end{array}$ & 2015 & Literature review & 6 & $\begin{array}{l}\text { Most }(88 \%) \text { of adolescents accessed cellular phones, } 73 \% \text { of } \\
\text { adolescents used cell phones to access the internet. Text messages } \\
\text { were faster and cheaper and could connect adolescents with health } \\
\text { information (Decker, Berglas, \& Brindis, 2015) }\end{array}$ \\
\hline 19. & $\begin{array}{l}\text { Negar Aliabadi, Alex Carballo-Dieguez, } \\
\text { Suzanne Bakken, } \\
\text { Marlene Rojas, William Brown III, } \\
\text { Monique Carry, } \\
\text { Jocelyn Patterson Mosley, Deborah } \\
\text { Gelaude, and Rebecca Schnall }\end{array}$ & 2015 & $\begin{array}{l}\text { Qualitatitive } \\
\text { research }\end{array}$ & 33 & $\begin{array}{l}\text { Adolescents wanted information about HIV risks and illnesses, HIV } \\
\text { screening locations and groups of supporters. Smartphone } \\
\text { application provided information on HIV screening locations, support } \\
\text { groups, prevention methods, HIV risk, and HIV disease/treatment } \\
\text { information (Aliabadi et al., 2015) }\end{array}$ \\
\hline 20. & Joan Geckle & 2016 & Literature review & 16 & $\begin{array}{l}\text { The use of multimedia, mobile technology, Short Messaging Service } \\
\text { (SMS) texting, and social networking (for example, Facebook®), in } \\
\text { the promotion of adolescent reproductive health and prevention of } \\
\text { disease at the age of } 10 \text { to } 20 \text { years. The use of SMS and social } \\
\text { media features for communication, in relation to health promotion } \\
\text { and disease prevention. (Geckle, 2016). }\end{array}$ \\
\hline
\end{tabular}


The results of the literature study showed that smartphone was used as KIE media for adolescent reproductive health based on applications, text messages, and social media such as girl talk, AKU, ARMADILO, BART, facebook. Girl Talk application was used on average for 48 minutes during leisure time with duration 10-15 minutes. Adolescents knowledge about anatomy and physiology increased $(4.2 \%)$, sexuality $(3.5 \%)$, and prevention of sexual transmition infections (3.4\%). As many as $94.1 \%$ of adolescents said that the application was informative and detailed compared to class-based health education (Brayboy et al., 2017). This media showed positive responses from adolescents because it was more attractive and free.

AKU was an application of adolescent reproductive health education which was developed through 3 stages, namely analysis, design, and development. As many as $85 \%$ of adolescents said this application was very good. This application could increase the knowledge of adolescents about reproductive health (94\%), as many as $85 \%$ of adolescents said the material in this application is easy to remember Novaeni et al, 2018).

ARMADILO applications based on text messages were more innovative, interesting, privacy-aware, and easily accessible. Information provided about family planning and contraceptive usages were accompanied by question and answer features (Gonsalves et al., 2015). In addition, the BART (Becoming a Responsible Teen) application based on text messages was also used as IEC media for adolescent reproductive health. This intervention was supplemented by face-to-face sessions every week to explore adolescents' acceptance of the application. The results of the intervention showed that adolescents who had sex without condom before intervention were 31 times to 19 times after intervention and 9 times after 3 months of internalization. Adolescent knowledge about HIV based on age increased significantly ( $p$ value $=$ 0.05 ), attitudes towards condom usages increased significantly ( $p$ value $=0.007$ ), and HIV risk based on age increased significantly ( $p$ value $=0.03$ ) and based on time ( $p$ value $=0.009$ ) (Cornelius et al., 2013). The increase in the variables studied was also an indication of the effectiveness of using text message-based applications for adolescents.

Social media was used to exchange information on adolescent reproductive health. Patel et al. (2016) states that the majority of adolescents have cell phones (87.3\%). The majority of adolescents $(67.6 \%)$ used this device to access the internet and social media such as Facebook and Twitter. Adolescents reported having at least one social media, most had multiple self-profiles (83.3\%). The majority of adolescents (87.3\%) accessed the internet and social media sites several times per day. Social media was felt to be more interactive, fun, practical, privacy maintained, and closer to health services (Aragão et al., 2018).

Adolescent problems were such as promiscuity, early marriage, unwanted pregnancies, and sexual transmition infections were still problems that required special attention in various countries, including in Indonesia. Handling these problems required strategic and integrative efforts through the use of information technology. Digital health technology played important role in health care, health education and self-supervision in the promotion of adolescent reproductive health (Lupton, 2015). The results of the literature study showed that the use of smartphone applications was effective in promoting adolescent reproductive health. Mobile phone technology seemed to answer adolescents' needs for fast and affordable health information. Besides that, it could be used to communicate directly with the other person and send short messages via text or SMS (Short Messages Service). Text messages are relatively cheaper and can disseminate information in a short time (Muflih \& Setiawan, 2017).

The mobile phone health (mHealth) application was as medium for promoting reproductive health for adolescents that could connect users with health information services, included 
counseling and family planning services, medical abortion and post-abortion care, as well as HIV care and treatment (Ippoliti \& L'Engle, 2017). Adolescents reported increased condom usages, participation in screening, HIV treatment and STIs, contraceptive use, and decreased incidence of gender-based violence. In addition, there were behavioral changes in the use of reproductive health services after being given interventions using SMS (Brody et al., 2018).

Text message based applications were effective way to minimize gaps, by providing accurate and complete information through the right media. In addition, text messages could be adjusted based on cultural and individual characteristics, broad targets, and affordable costs. Text messages had been considered for use in efforts to improve knowledge of adolescent reproductive health (Rokicki, Cohen, Salomon, \& Fink, 2017). Text messages were also used as a promotion of reproductive health services, reduced sexual risk behavior, and efforts to reduce bias data in reporting sexual activity via SMS. The results of the study by Burns et al. (2016) reported a significant increase in sexual health services using SMS. The counseling mechanism with SMS Gateway was done by sending a message contained reproductive health information that was equipped with a question and answer facility and discussion (Muflih and Setiawan, 2017)

Adolescents showed positive response about the use of Facebook in health education, with consideration of the provided information, more practical, and many users. This had to be strengthened by the existence of advanced research examined the effectiveness of other social media as a medium for the promotion of adolescent reproductive health (Aragão et al.2018). Other things that needed to be considered in the development of social media were forms attractive social media, membership, access to health and social services, risk of conflict among adolescents, and implications for the prevention of sexual diseases such as HIV and STIs (Bull et al., 2013).
The use of online and mobile technologies (OMT) through smart phones was an opportunity for risky ethnic minority adolescents. OMT was able to increase the motivation of parents and adolescents to obtain reproductive health information because of easy access and extensive information (Guilamo-Ramos et al., 2014). Guse et al (2012) explained that internet, text messaging, and social networking sites were preferred by adolescents because they were able to effectively bridge barriers to communication, which were more dynamic in health promotion efforts and minimized health risks (Shaw, Mitchell, Welch \& Williamson, 2015).

Several other literature studies explained different results on increasing knowledge. This was due to differences in the number of adolescents, the length of intervention, the level of education and the socioeconomic levels so that the achievements of each study were different although they were still in a significant level. Improving the quality of life of adolescents was inseparable from the support of groups or communities who always provided assistance and attention to all experienced obstacles. Denno, Hoopes and Mouli (2014) stated that the contribution of groups or communities cannot be separated from the effectiveness of outcomes from reproductive health education, social norms and cultural practices, the ability to access reproductive health services (Kaufman, Cornish, Zimmerman \& Johnson, 2014). Based on this, family and community support also played a role in the outcomes of the reproductive health education process.

The innovation of KIE media based on smart phone applications was open-access to adolescents to get information quickly and precisely so that the results obtained were more optimal than other media. Improving adolescent health status was a reflection of the effectiveness of interventions. The use of this media was an opportunity in developing interventions because there were 82 million internet users in Indonesia where $80 \%$ of them were teenagers aged 15-19 years. Indonesia was the fourth in 
the world for internet usage (Indonesian Ministry of Communication and Information, 2014). This was supported by the UNICEF study involving 400 respondents aged 10-19 years throughout Indonesia and representing urban and rural areas. There were $98 \%$ of children and adolescents knew about internet and $79.5 \%$ of them were internet users (Panji, 2014).

Smartphone applications are very accessible to teenagers. The availability of easy access for IEC is very much needed considering that around $23 \%$ of middle school age and $41 \%$ of high school age do not attend school, meaning that they do not receive health coaching like children who attend school. This shows how large the number of adolescents needs a place that is easily accessible to complete and discuss their health problems other than the available health facilities (Kemenkes $\mathrm{Rl}, 2018$ ).

Therefore, the development of KIE media based smartphone applications in the future is very necessary, to improve the quality of health and changes in teenage sexual behavior. All the findings of the above literature indicate that smartphone applications can improve adolescent reproductive health. Based on the results of research from Kominfo $\mathrm{RI}$ (2014), the use of social media was more effective as KIE media for adolescents. The study found that $98 \%$ of the children and adolescents knew about internet and $79.5 \%$ of them were internet users. Children and adolescents in Indonesia have three main motivations in accessing the internet, namely to seek information, to connect with friends (old and new) through social media, and entertainment media. Aprilianto (2018) also added that social media was major human need. Social media was more easily connected communication with friends and distant families. For young people, social media was used more diverse such as Facebook, Twitter, blog, line, BBM, and Youtube. Therefore, social media was most effectively used as KIE media for adolescent in Indonesia. However, the use of smartphone applications has several disadvantages, but in the process of using it requires stable internet access and people's purchasing power for smartphones. The limitations of this article are the limited number of related research articles that use randomized controlled trials.

\section{CONCLUSION}

The use of smartphone applications presents an opportunity to reach population of risk adolescents. Utilization of smart phone applications as reproductive health can be through applications, SMS, and social media such as Facebook and Twitter. The use of social media was effectively seen as KIE media for adolescent. The use of smartphone applications can be integrated with adolescent health programs that have been running in Indonesia such as the School Health Program (UKS) and Youth Health Care Services (PKPR).

\section{REFERENCES}

Aliabadi, N., Carballo-dieguez, A., Bakken, S., Rojas, M., lii, W. B., Carry, M., ... Schnall, R. (2015). Using the information-motivation- behavioral skills model to guide the development of an HIV prevention smartphone application for high-risk MSM, AIDS Education and Prevention: Official Publication of the International Society for AIDS Education,27(6), 522-537.

Aprilianto, M.B. (2018). Media sosial teraktif di Indonesia mana yang sering digunakan. https://www.brilio. net/wow/10-media-sosial-teraktif-diindonesia-mana-yang-sering-kamupakai-180214v.html. Diakses 1 Januari2018.

Aragão, J. M., Gubert, F. D., Torres, R. A., Silva, A. S., \& Vieira, N. F. (2018). The use of Facebook in health education: Perceptions of adolescent students. Revista Brasileira De Enfermagem, 71(2), 265-271. doi:10.1590/0034-7167-2016-0604

Brayboy, L. M., Schultz, L., Mills, B. S. L., Sepolen, A., Mezoian, T., Wheeler, 
C., \& Clark, M. A. (2017). Girl talk: a smartphone application to teach sexual health education to adolescent girls. Journal of Pediatric and Adolescent Gynecology, 30(1), 23-28.

http://doi.org/10.1016/j.jpag.2016.06. 011.Girl

Brody, C., Tuot, S., Chhoun, P., Swendenman, D., Kaplan, K. C., \& Yi, S. (2018). Mobile Link - a theorybased messaging intervention for improving sexual and reproductive health of female entertainment workers in Cambodia: Study protocol of a randomized controlled trial. Trials, 19(1), 1-15. http://doi.org/10. 1186/s13063-018-2614-7

Bull, S. S., Levine, D. K., Black, S. R., Schmiege, S. J., \& Santelli, J. (2012). Social media-delivered sexual health intervention. American Journal of Preventive Medicine, 43(5), 467-474. doi:10.1016/j. amepre.2012.07.022

Burns, K., Keating, P., \& Free, C. (2016). A systematic review of randomised control trials of sexual health interventions delivered by mobile technologies. BMC Public Health, 16(1), 1-14. https://doi.org/10.1186/ s12889-016-3408-z

Cornelius, J. B., Dmochowski, J., Boyer, C., Lawrence, J. S., Lightfoot, M., \& Moore, M. (2013). Text-MessagingEnhanced HIV intervention for African American adolescents: A Feasibility Study. Journal of the Association of Nurses in AIDS Care, 24(3), 256-267. doi:10.1016/j.jana .2012.06.005

Decker, M., Berglas, N., \& Brindis, C. (2015). A call to action: Developing and strengthening new strategies to promote adolescent sexual health. Societies, 5(4), 686-712. http://doi. org/10.3390/soc5040686
Denno, D. M., Hoopes, A. J., \& ChandraMouli, V. (2015). Effective strategies to provide adolescent sexual and reproductive health services and to increase demand and community support. Journal of Adolescent Health, 56(1), 22-41. doi:10.1016/j. jadohealth.2014.09.012

Dowshen, N., Lee, S., Lehman, B. M., Castillo, M., \& Mollen, C. (2015). Iknowushould2: feasibility of a youthdriven social media campaign to promote STI and HIV testing among adolescents in Philadelphia. AIDS and Behavior, 19(S2), 106-111. doi:10.1007/s10461-014-0991-9

Geckle, J. (2016). Use of multimedia or mobile devices by adolescents for health promotion and disease prevention: A literature review, 42(4), 163-168.

Gonsalves, L., Hindin, M. J., Bayer, A., Carcamo, C. P., Gichangi, P., Habib, N., ... Say, L. (2018). Protocol of an open, three-arm, individually randomized trial assessing the effect of delivering sexual and reproductive health information to young people (aged 13-24) in Kenya and Peru via mobile phones: adolescent/youth reproductive mobile access and $d$. Reproductive Health, 15(1), 126. https://doi.org/10.1186/s12978-0180568-6

Guilamo-Ramos, V., Lee, J. J., Kantor, L. M., Levine, D. S., Baum, S., \& Johnsen, J. (2014). Potential for using online and mobile education with parents and adolescents to impact sexual and reproductive health. Prevention Science, 16(1), 53-60. https://doi.org/10.1007/s 11121-014-0469-z

Guse, K., Levine, D., Martins, S., Lira, A., Gaarde, J., Westmorland, W., \& Gilliam, M. (2012). Interventions using new digital media to improve adolescent sexual health: A systematic review. Journal of 
Adolescent Health, 51(6), 535-543. doi:10.1016/j.jadohealth.2012.03.01 4

Ippoliti, N. B., \& L'Engle, K. (2017). Meet us on the phone: Mobile phone programs for adolescent sexual and reproductive health in low-to-middle income countries. Reproductive Health, 14(1), 1-9. https://doi.org/10.1186/s12978-0160276-z

Kaufman, M. R., Cornish, F., Zimmerman, R. S., \& Johnson, B. T. (2014). Health behavior change models for HIV prevention and AIDS care. JAIDS Journal of Acquired Immune Deficiency Syndromes, 66, 250-258. doi:10.1097/qai.0000000000000236

Kementerian Kesehatan RI Direktorat Jenderal Kesehatan Masyarakat. (2018). Petunjuk teknis penyelenggaraan posyandu remaja. Jakarta: Kementerian Kesehatan RI.

Kominfo RI. (2014). Penggunaan internet di Indonesia. https://kominfo.go.id/index.php/conte nt/detail/3980/Kemkominfo\%3A+Pen gguna+Internet+di+Indonesia+Capai $+82+J u t a / 0 /$ berita_satker.

Kominfo RI. (2014). Riset Kominfo dan UNICEF mengenai perilaku anak dan remaja. ttps://kominfo.go.id/ index.php/content/detail/3834/Siaran +Pers+No.+17-PIH-KOMINFO-2-20 $14+$ tentang+Riset+Kominfo+dan+U $\mathrm{NICEF}+$ Mengenai+Perilaku+Anak+d an+Remaja+Dalam+Menggunakan+l nternet+/0/siaran_pers

Lupton, D. (2015). Quantified sex: A critical analysis of sexual and reproductive self-tracking using apps, 17(4), 440-453.

Muflih \& Setiawan, D. I. (2017). Pengaruh konseling short message service (SMS) gateway terhadap self efficacy menghindari seks bebas dan hiv/aids remaja. JKP, 5(April 2017), 1-9.

Muslimah, A. Dan Prakoso, D. A. (2014). Efektifitas edukasi melalui media SMS (short messages service) terhadap peningkatan pengetahuan tentang kesehatan reproduksi pada remaja siswa sekolah menengah pertama. Fakultas Kedokteran UMY

Novaeni, N., Dharminto, Agusyahbana, F., \& Mawarni, A. (2017). Pengembangan aplikasi edukasi kesehatan remaja berbasis android untuk pembelajaran biologi di SMA Pius Kabupaten Purworejo tahun 2017. Jurnal Kesehatan Masyarakat http://ejournal3.undip.ac.id/index.php /jkm.

Ortiz, R. R., Shafer, A., Cates, J., \& Coyne-Beasley, T. (2018). Development and evaluation of a social media health intervention to improve adolescents' knowledge about and vaccination against the human papilloma virus. Global Pediatric Health, 5, 1-10. doi:10.1177/2333794×18777918

Panji. (2014). Pemakaian internet remaja Indonesia. https://tekno.kompas. com/read/2014/02/19/1623250/Hasil. Survei.Pemakaian.Internet.Remaja.I ndonesia.

Patel, V. V., Masyukova, M., Sutton, D., \& Horvath, K. J. (2016). Social media use and HIV-related risk behaviors in young black and latino gay and bi men and transgender individuals in New York City: implications for online interventions. Journal of Urban Health, 93(2), 388-399. http://doi.org/10.1007/s11524-0160025-1

Rokicki, S., Cohen, J., Salomon, J. A., \& Fink, G. (2017). Impact of a textmessaging program on adolescent reproductive health: A clusterrandomized trial in Ghana. American Journal of Public Health, 107(2), 
298-305. doi:10.2105/ajph.2016. 303562

Sarweni, K. P., \& Hargono, R.. (2010). Demand vs supply program kesehatan remaja di Puskesmas Tanah Kalikedinding Surabaya, 7181.

Shaw, J. M., Mitchell, C. A., Welch, A. J., \& Williamson, M. J. (2015). Social media used as a health intervention in adolescent health: A systematic review of the literature. Digital Health, 1, 1-10. doi:10.1177/205520 7615588395 